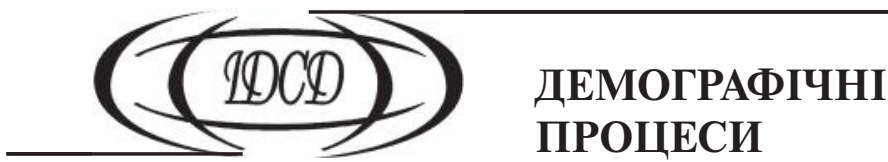

Doi: https://doi.org/10.15407/dse2018.02.11

УДК: 331.556.4(477)

JEL Classification: J61

\section{Е.М. ЛІБАНОВА}

академік НАН України, д-р екон. наук, проф., дир.

Інститут демографії та соціальних

досліджень імені М.В. Птухи НАН України

01032, м. Київ, бул. Шевченка, 60

E-mail:libanova@ukr.net

\section{ЗОВНІШНІ ТРУДОВІ МІГРАЦІЇ УКРАЇНЦІВ: МАСШТАБИ, ПРИЧИНИ, НАСЛІДКИ}

Розглянуто основні причини та наслідки зовнішньої міграції з України. Виявлені складові міграції та вплив кожної на загальну соціально-економічну ситуацію в країні та життя родини мігрантів. Дано характеристику масштабів міграції, ї̈ структури за країнами тяжіння. Окреслено можлливості впливу держави на міграційну поведінку населення і висвітлено найбільш ефективні, з точки зору автора, дії. Надана оцінка масштабів зовнішньої міграції з України. Наслідки масштабної трудової міграції є дуже різними. Оцінювати значення і наслідки кожного конкретного виду міграцій необхідно з урахуванням інтересів світового розвитку, країни витоку мігрантів та їхніх родин. Виявлено, що велика частина активного, мобільного і конкурентоспроможного населення пов'язує можливості радикальних змін із зовнішньою міграцією. Загальна низька оцінка і ситуації в країні, і свого індивідуального життя, що акумулюється індексом соціального самопочуття, трансформується в бажсання багатьох українців, особливо молодих, активних і конкурентоспроможних, виїхати за кордон на постійне місце проживання або, принаймні, на роботу чи навчання. Визначено, що головним мотивом виїзду більшості українців $\epsilon$ надія отримувати значно більшу зарплату, але економічні чинники завжди діють у певному ментальному середовищі, зокрема реалізованому в конкретному рівні міграційної мобільності. Міграційна мобільність українців (як і поляків, німців, естонців, литовців, ірландців, італійців) є доволі високою на відміну від франиузів, угорців, болгар. Тому підвищення зарплат до співставного з сусідніми країнами рівня, безперечно, зменшить масштаби поширення міграційних настроїв, але не скасує їх повністю.

Ключові слова: зовнішня міграція, міграційна поведінка, причини виїзду, наслідки зовнішньої міграції.

\section{Э.М. Либанова}

акад. НАН Украины, д-р экон. наук, проф., дир.

Институт демографии и социальных

исследований имени М.В. Птухи НАН Украины

01032, г. Киев, бул. Шевченко, 60

E-mail: libanova@ukr.net 


\section{ВНЕШНИЕ ТРУДОВЫЕ МИГРАЦИИ УКРАИНЦЕВ: МАСШТАБЫ, ПРИЧИНЫ, ПОСЛЕДСТВИЯ}

Рассмотрены основные причины и последствия внешней миграции из Украины. Выявлены составляющие миграции и влияние каждой на общую социально-экономическую ситуацию в стране и жизни семьи мигрантов. Дана характеристика масштабов миграции, ее структуры по странам притяжения. Определены возможности влияния государства на миграционное поведение населения и освещены наиболее эффективные, с точки зрения автора, действия. Дана оценка масштабов внешней миграции из Украины. Последствия масштабной трудовой миграции очень разные. Оценивать значение и последствия каждого конкретного вида миграций следует с учетом мирового развития, страны убытия мигрантов и их семей. Определено, что большая часть активного, мобильного и конкурентоспособного населения связывает возможности радикальных изменений с внешней миграцией. Общая низкая оценка и ситуации в стране, и своей индивидуальной жизни, которая аккумулируется индексом социального самочувствия, трансформируется в желание многих украинцев, особенно молодых, активных и конкурентоспособных, выехать за гранииу на постоянное место жительства или, по крайней мере, на работу или учебу. Определено, что главный мотив выезда большинства украинцев - надежда получать значительно большую зарплату, но экономические факторы всегда действуют в определенной ментальной среде, в частности реализованной в конкретном уровне миграционной мобильности. Миграционная мобильность украиниев (как и поляков, немиев, эстонцев, литовцев, ирландцев, итальянцев) довольно высока, в отличие от франиузов, венгров, болгар. Поэтому повышение зарплат до сопоставимого с соседними странами уровня, безусловно, уменьшит масштабы распространения миграционных настроений, но не ликвидирует их полностью.

Ключевые слова: внешняя миграция, миграционное поведение, причины выезда, последствия внешней мигращии.

\section{E.M. LIBANOVA}

Academician of NAS of Ukraine, Dr. Sc. (Economics), Prof., director

Ptoukha Institute for Demography and Social Studies

of the National Academy of Sciences of Ukraine

01032, Kyiv, Taras Shevchenko Blvd, 60

E-mail: libanova@ukr.net

\section{EXTERNAL LABOR MIGRATION OF UKRAINIANS: SCALE, CAUSES, CONSEQUENCES}

The role of external migration in the modern and future development of Ukraine is defined. Its main components are considered, differing in the duration of their stay abroad, the composition of participants, the impact on the overall social and economic situation in the country and the life of migrant families. The short agrarian migration, short non agrarian migration, long migration, brain drain, educational migration and going to a permanent place of residence are highlighted, their effects are characterized from position of Ukrainian economy and migrant's household. The scale and texture of migratory flows in the countries of destination is clarified. The author highlights various estimates of the scale of migration and explains the reasons for these differences, she leads calculations of migration mobility of difference groups of Ukrainian population. It is shown that external migrations in modern Ukraine perform the functions of social elevators, and declaring intentions of leaving the country has become a mode of behavior. The reasons of international migration are studied and the author's conclusion follows: the main factor is differences between wage in Ukraine and potential remuneration in the country of destination, but the important role plays mentality. This thesis author illustrates by examples of Poland and Hungary: Poland is leader of Eastern European countries according to reforms, the economic growth, living standards and simultaneously polish population emigration rate; Hungary economy remains poorly reformed, the economic growth is low, but migration mobility is poor. Due to traditional high mobility of Ukrainians the idea stopping of external migration solely through the growth of wages is unreasonable. The possibilities of state influence on the migration behavior of the population are outlined and the most effective actions, from the point of view of the author, are highlighted.

Keywords: external migration, migration behavior, reasons for leaving, consequences of external migration. 
Постановка проблеми та її актуальність. Міграційний обмін населенням є однією з головних складових глобалізації, формування транснаціональних ринків праці, створення єдиного освітнього, культурного, мовного простору, долучення всіх землян до результатів цивілізаційного прогресу. На відміну від міграцій XVII-XIX ст., спрямованих переважно в один бік (із країн старого світу до Америки, Австралії, Нової Зеландіï), сучасні набули різноспрямованого характеру, часто зворотного, і навіть доволі хаотичного. Що далі, то частіше людина не просто живе і працює не в країні свого походження, а упродовж життя декілька разів змінює країну проживання. Видається, що в майбутньому обсяги міжнародного міграційного обміну населенням зростатимуть, а тривалість перебування мігранта в одній країні скорочуватиметься.

Мета роботи - розглянути основні причини та наслідки зовнішньої міграції 3 України, визначити складові міграції і вплив кожної на загальну соціально-економічну ситуацію в країні та життя родини мігрантів.

Виклад основного матеріалу. Найпоширенішими в світі та панівним в Україні $€$ т. зв. економічні міграції, зокрема, трудові. Вони формуються під впливом різних чинників, розрізняються за складом та масштабами, але мають і спільні риси: головним поштовхом є можливість більше заробляти або отримати кращі можливості для реалізації свого потенціалу, рух спрямований до країн з вищим рівнем життя, лише невелика частина трудових мігрантів, які знайшли прийнятне місце роботи в новій країні, повертаються на батьківщину.

Оцінка масштабів зовнішньої міграції з України. Наразі вкрай важко оцінити масштаби зовнішньої міграції українців (а структуру та напрями й поготів) - даються взнаки і загальні проблеми обліку населення через 17 років після проведення Перепису, i відсутність дієвих стимулів реєструвати переїзд, і неготовність родичів трудових мігрантів повідомляти інтерв'юерів про роботу за кордоном когось із родини, особливо 3 огляду на поширення останнім часом чуток про наміри уряду оподатковувати доходи, отримані за кордоном. Практично всі експерти погоджуються з тим, що тривалість роботи за кордоном переважної більшості українських заробітчан, які повернулися до України, не перевищує одного року, проте 29 \% працювали понад рік, а 14 \% - кілька років [1]. Найбільша частка т. зв. короткострокових мігрантів ${ }^{1}$ характерна для сусідніх Польщі та Чехії. Цілком очікувано третина працюючих в Італії не повертається до України понад рік ${ }^{2}$. Тривалість однієї поїздки левової частини українських трудових мігрантів не перевищує 3-х місяців, проте більшість виїжджає упродовж року декілька разів. І якщо раніше висока міграційна мобільність спостерігалась переважно в західних областях, то наразі вона поширилась і на центральні та південні райони. Досвід роботи за кордоном у більшості, вочевидь, є позитивним - $71 \%$ заробітчан хотіли б у майбутньому знову працювати за межами України [1].

Загальна чисельність українських трудових мігрантів, які одночасно працюють за кордоном, коливається від 1,5 до 5,0 млн осіб ${ }^{3}$. 3 огляду на чисельність осіб, які

\footnotetext{
${ }^{1}$ Особи віком 15-50 років, які хоча б один раз упродовж спостереження 2015-2017 рр. були відсутні менше року через виконання або пошук роботи за кордоном із очікуванням повернення впродовж наступних 12 місяців. ${ }^{2}$ Розраховано за даними Державної служби статистики України. URL: http://www.ukrstat.gov.ua/druk/publicat/ kat_u/2017/bl_ztmz-2017.zip

${ }^{3}$ Найменше традиційно оцінює міграцію Державна служба статистики, яка вважає трудовими мігрантами тільки тих, хто перебуває за кордоном менше одного року (інші не відповідають критеріям постійного населення країни походження і вважаються емігрантами): за даними Держстату, упродовж 2005-2008 рр. за кордоном до одного року одночасно працювали понад 1,1 млн осіб, упродовж 2010-2012 - 1,2 млн, упродовж 2015-2017 - 1,3. Переважна більшість інших продукувачів інформації не ставить таких обмежень, тому результати їх досліджень дають вищі оцінки.
} 
сплачують податки в Україні, масштаби незареєстрованої зайнятості та імовірні помилки обліку, найбільш вірогідною видається оцінка чисельності одночасно працюючих за кордоном українців у 3,0 млн осіб.

За останні роки міграційні потоки з України зазнали кардинальних змін, але змінилися не стільки масштаби, скільки напрями та співвідношення зворотних та незворотних міграцій (рис.1). I спричинено такі трансформаціі радше зовнішніми, ніж внутрішніми подіями. Орієнтація на модель економіки з дешевою робочою силою, трактування низьких зарплат як головної конкурентної переваги України зберігається упродовж дуже тривалого періоду, і вплив низьких зарплат на мотивацію трудових міграцій є постійним. Натомість змінився попит на українську робочу силу, змінилися умови працевлаштування за кордоном.

Упродовж 2,5 десятиліть потоки трудової міграції з України ділилися майже навпіл між Росією та Європою, причому обмін робочою силою з Росією мав яскраво виражений циркулярний характер, а більшість українських заробітчан в європейських країнах намагалися залишитися там якщо не назавжди, то принаймні на тривалий час. Все змінилося з початком збройного конфлікту на Донбасі й відповідним різким погіршенням відносин між двома країнами - чисельність охочих працювати в Росії стрімко скоротилась. Проте, хоча від початку російської військової агресії минуло вже чотири роки, більшість українців вважають цілком нормальним заробітчанство на території країни-агресора: 63,1 \% виправдовують таку практику і тільки 22,1\% категорично ії не сприймають [2]. Безперечно, на переорієнтацію потоків впливає і те, що можливості заробітків у Росії істотно поступаються таким у європейських країнах. I хоча в 2014-2015 рр. потік мігрантів з Донбасу та Криму до Росії навіть збільшився, наразі та частина тамтешніх жителів, які вимушено залишили свої місця проживання через загрозу життю, руйнування житла, втрату роботи тощо і переїхали до інших регіонів України, достатньо часто формують вторинний потік спрямований до економічно розвинутих країн. Основним мотивом є прагнення більше заробляти, зокрема для придбання / оренди житла, але не варто нехтувати і бажанням уникнути призову до збройних сил.

Однак головним чинником переорієнтації міграційних потоків стала зміна ситуації в країнах, що є традиційними реципієнтами української робочої сили, передусім зміна балансу попиту та пропозиції робочої сили на їхніх ринках праці, економічна

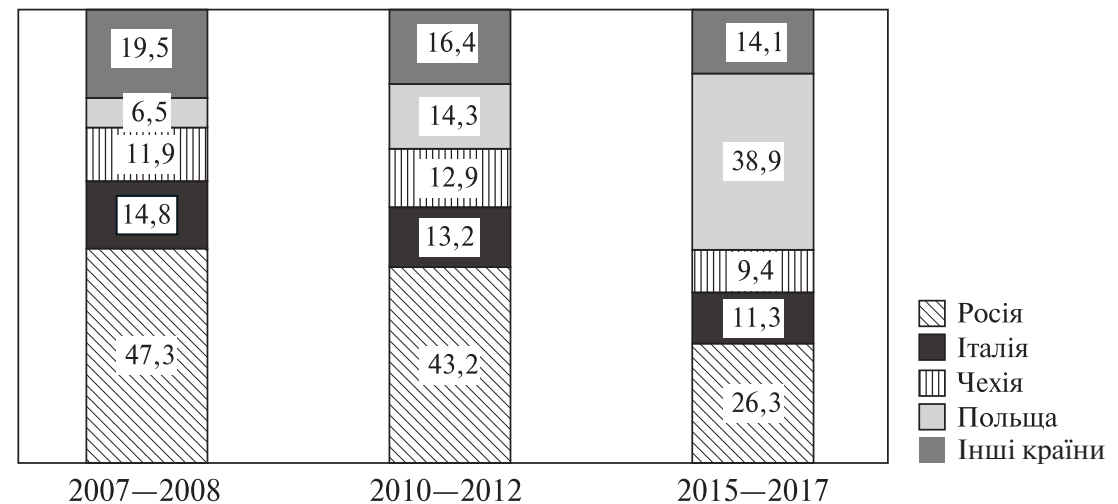

Рис. 1. Структура потоків зовнішніх міграцій, за країнами призначення, \%

Джерело: Державна служба статистики України. 
доцільність збільшення набору студентів до закладів професійної освіти та відповідне спрощення процедур надання іноземцям, зокрема українцям, дозволів на роботу та / або навчання.

Складна ситуація на ринках праці більшості східноєвропейських країн, обумовлена, головним чином, відпливом значної частини їхніх громадян на заробітки до більш розвинутих економік з вищою зарплатою і кращими перспективами, змушує спрощувати процедури працевлаштування і знижувати вимоги до робочої сили. Якщо ще кілька років тому роботодавці Польщі, Чехії, Словаччини наймали на роботу переважно досвідчених кваліфікованих працівників (за винятків випадків, коли потрібна була некваліфікована робоча сила), то наразі вони погоджуються навіть на підготовку / перепідготовку за власний кошт упродовж 1-2 місяців.

До цього додалося набуття безвізового статусу, а отже, можливості, по-перше, цілком легально перебувати в європейських країнах упродовж трьох місяців поспіль, підшукуючи собі прийнятну роботу. У поєднанні із докорінним спрощенням Польщею процедури отримання українцями т. зв. робочої візи та відсутністю мовного бар'єру (принаймні в усному спілкуванні) це закономірно спричинило зростання потоку трудових мігрантів з України саме до Польщі. Сюди треба додати дуже активне заохочення учбової міграції української молоді з боку професійних навчальних закладів більшості східноєвропейських (і не тільки) країн - відкриваються спеціальні програми, надаються гранти та стипендії, працюють спеціальні підготовчі мовні курси.

Про зміну географічної структури українських мігрантів свідчить, зокрема, зміна структури приватних грошових переказів. Тільки за 2015-2017 роки обсяг переказів із Польщі збільшився на 138,5 \%, з інших країн ЄС - на 23,8 \%, із США та Канади - на $33,3 \%$, тоді як з Росії, навпаки, зменшився на 27,8 \% ${ }^{4}$.

Причини міграційного відпливу. Населення України постійно демонструє незадоволення як власним життям, так і ситуацією в країні. Значною мірою це обумовлене дійсно низьким рівнем життя і низькими темпами та незадовільною якістю соціальноекономічних трансформацій. Але видається, що не менше значення має величезний розрив між завищеними очікуваннями в контексті наслідків Революції гідності і фактичною ситуацією. Так, українці сподівались на швидке підвищення доходів, поліпшення якості і розширення доступності всіх публічних послуг, і частина цих очікувань справдилась. Проте, водночас стрімке падіння курсу гривні зробило недоступними частину імпортних товарів. Події на Донбасі не тільки позбавили Україну значної суми надходжень до бюджету і фондів загальнообов'язкового соціального страхування, а водночас і значно збільшили бюджетні витрати на підтримку вимушених переселенців, на переозброєння армії, на періодичне відновлення об'єктів інфраструктури на територіях, прилеглих до зони ОРДЛО, що систематично руйнуються внаслідок обстрілів, на облаштування і підтримку функціонування численних контрольно-пропускних пунктів уздовж лінії розмежування тощо. Безперечно, це не може не позначатися на фінансовій спроможності держави виконувати свої зобов'язання щодо населення. Даються взнаки і традиційні для молодої демократії, якою є Україна, політичні спекуляції, прагнення популізму з боку політиків і патерналізму з боку значної частини громадян.

Імовірно, саме тим, що очікування більшості населення пов'язане із зовнішніми діями (Уряду, Президента, місцевої влади, допомогою міжнародних структур та / або провідних країн світу), а не з бажанням здійснювати активні заходи власноруч, пояс-

\footnotetext{
4 Розраховано за даними: Національний банк України «Перерахунок даних щодо приватних грошових переказів в Україну за 2015-2017 роки». URL: https://bank.gov.ua/control/uk/publish/article?art_id=63075631\&cat_ $\mathrm{id}=55838$
} 
нюється певне заниження самооцінок доходів і власного статусу. Однак у середньому українці набагато більше задоволені своїм власним життям, ніж ситуацією в країні загалом [3]. Зрозуміло, що на оцінки власного життя впливає особистий досвід, а уявлення про ситуацію в країні пересічний українець формує зі 3МI, які переважно дають негативну інформацію.

Звісно, низькі оцінки власного і суспільного буття спричиняють бажання змін. На жаль, велика частина активного, мобільного і конкурентоспроможного населення пов’язують можливості радикальних змін із зовнішньою міграцією, і загальна низька оцінка і ситуації в країні, і свого індивідуального життя, що акумулюється індексом соціального самопочуття, трансформується в бажання багатьох українців, особливо молодих, активних і конкурентоспроможних, виїхати за кордон на постійне місце проживання або на роботу чи навчання. Принаймні таке зазначають 29-35 \% осіб віком від 18 років, опитаних наприкінці 2017 року [3]. Проте тільки $62 \% 37 \%$ українців, які мають наміри упродовж найближчих шести місяців виїжджати на тривалий (понад три місяці) термін, здійснюють необхідні кроки (4,5 \% загальної чисельності населення 18+) - це близько 1,5 млн осіб 18-64 років [4]. Безперечно, це значна сукупність населення. Але все ж таки не більшість, про яку часто говорять і політики, і 3MI.

Найчастіше мотивує до еміграції надія отримати кращі умови життя (64 \% тих, хто хотів би назавжди виїхати з України), бажання забезпечити краще майбутнє дітям (34 \% загалом і $21 \%$ тих, хто не має дітей до 16 років), відсутність в Україні достойної роботи $(23 \%)$ та прагнення отримати кращу освіту $(12 \%)^{5}$.

Істотно відрізняються від мотивів виїзду на постійне місце проживання чинники трудової міграції - тут домінує мотив прагнення гідних заробітків. І це цілком зрозуміло: навіть за елімінування різної купівельної спроможності середня зарплата в Україні становить лише третину такої в Польщі, Словаччині або Чехії, трохи більше половини - в Португалії, Греції або Російській Федерації, а мінімальна - приблизно половину аналогу в більшості європейських країн (рис. 2).

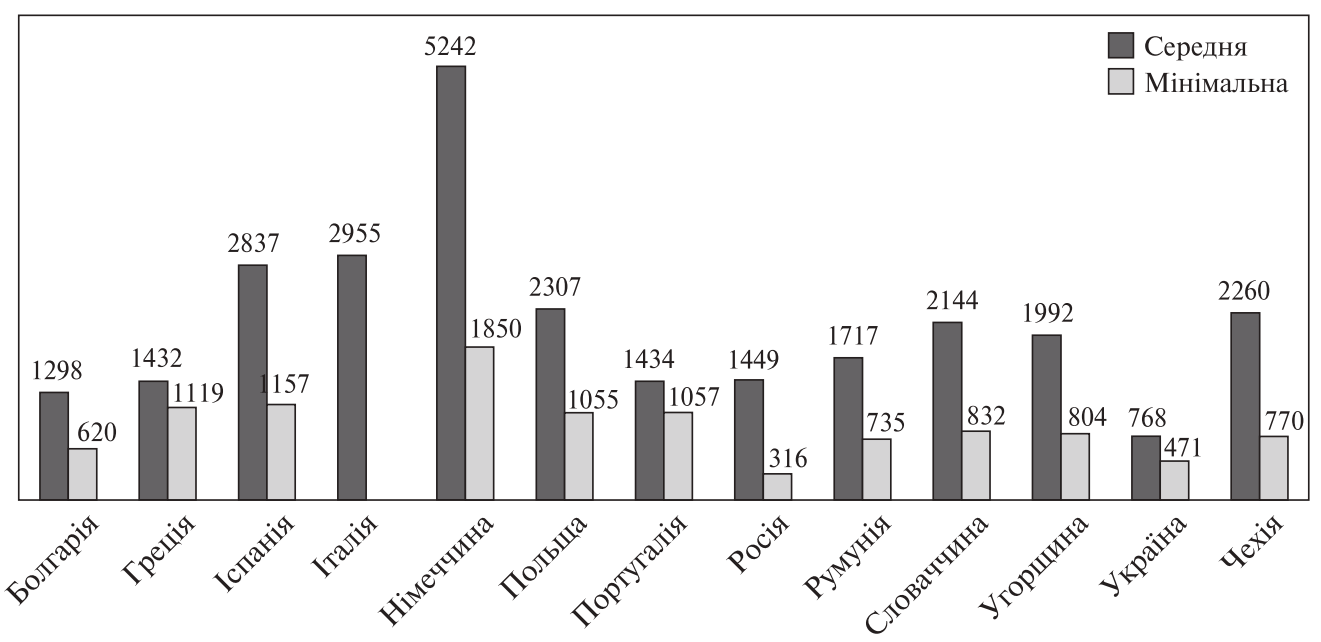

Рис. 2. Місячна заробітна плата, дол.США за ПКС-2011, 2016 рік

Джерело: ILOSTAT, WorldBank, Державна служба статистики України.

\footnotetext{
$\overline{5}$ Респонденти могли давати не більше двох відповідей.
} 
Більш-менш співставні із сусідніми країнами заробітки отримують в Україні працівники IT та далекобійники. У більшості професій зарплата в Україні в 2-3 рази нижча ніж, наприклад, у Польщі - країні, яка концентрує основну частину українських трудових мігрантів. Найбільше відставання спостерігається в медицині: середня офіційна зарплата лікаря в Україні в 6-10, а медичної сестри - в 6-8 разів нижча за таку в сусідній Польщі. Відповідно саме цю причину зазначили 72 \% тих, хто хотів би працювати за кордоном (другу за поширеністю причину - різницю в умовах праці - зазначили лише 20 \%). І дійсно, переважна більшість (81 \%) трудових мігрантів, які повернулися до України, задоволені своїми закордонними заробітками, при чому $79 \%$ (у Польщі 83 \%, а в Італії - 66) українських трудових мігрантів витрачали менше чверті заробленого [5]. Оскільки середній місячний заробіток трудового мігранта в Італії становить 937 дол. США, в Чехії - 793, а в Польщі - 584 [5], різниця пов'язана радше з відмінностями в заробітках, ніж в умовах проживання.

Проте люди часто перебільшують значення саме економічних чинників. У цьому контексті варто звернути увагу на Польщу, яка є не тільки центром тяжіння українських заробітчан, а й визнаним лідером Східної Європи за темпами та якістю реформ, за параметрами економічного розвитку загалом. Попри все це, попри задоволеність поляків своєю владою, рівнем життя та ситуацією в країні велика їх частина прямує до більш розвинених країн $Є С$ у пошуках кращої роботи, вищих доходів та ліпшого життя. Саме для заміни емігрантів і заповнення звільнених ними робочих місць шукають українських працівників польські роботодавці. Аналогічна ситуація складається і в Чехії, Словаччині, в країнах Балтії. Натомість угорці, попри своє відставання і в реформах, і в рівні життя, і в економічній динаміці загалом зовсім не демонструють таку мобільність. Скоріше за все, економічні чинники - безумовно, дуже важливі - діють у певному ментальному середовищі, яке посилює чи послаблює їхній вплив. Отже, різні сукупності населення мають різний потенціал мобільності, доволі стабільний та інерційний. 3 огляду на те, що українці ще за часів СРСР охоче зголошувались працювати на різноманітних «будівництвах комунізму», на тимчасову і навіть вахтову роботу у північно-східних регіонах тощо, їм загалом притаманна висока потенційна мобільність, а отже, за інших рівних умов вони більше налаштовані на роботу в інших країнах, ніж, скажімо, білоруси, угорці або болгари.

Істотно посилює схильність українців працювати за кордоном і поширеність перебільшення досягнень сусідів, включно із доходами та якістю життя загалом, на фоні применшення своїх. Результатом є престижність роботи і навчання за кордоном. Ті соціальні зв'язки, що протидіють переходу на роботу з нижчим статусом, але з вищою зарплатою в Україні, не тільки не впливають на готовність працювати на некваліфікованих роботах за кордоном, а навіть посилюють іiі. Те саме стосується і навчання в середніх професійних закладах. Так, попри очевидну нестачу на українському ринку праці кваліфікованих робітників чи не за всіма спеціальностями, попит на професійно-технічну освіту залишається вкрай низьким: ії планують отримати лише 14 \% учнів шкіл, тоді як на здобуття вищої освіти налаштовані 85 \%, при чому $73 \%$ молодих людей, які хочуть отримати вищу освіту, обмежитись професійнотехнічною освітою не погодилися б навіть за умови вищої зарплати та стабільності [6, с. 25]. Але українська молодь охоче зголошується на набуття робітничої професії, наприклад, у Польщі. Очевидно, що будь-яке навчання за кордоном сприяє підвищенню соціального статусу і молодих людей, і їхніх батьків, тоді як навчання у професійно-технічних закладах його, навпаки, сильно знижує.

Налаштованість на еміграцію - постійну або тимчасову - стає своєрідним must have, а участь у зовнішніх міграціях фактично перетворилась на соціальний ліфт, 
за допомогою якого можна швидко вирватися зі злиднів, отримати «перепустку» в суспільство з високим рівнем та якістю життя. Тому, хоча левова частка українців пояснює своє бажання працювати за кордоном винятково неможливістю отримувати гідні заробітки в Україні, насправді мотивація є значно складнішою.

Наслідки масштабної міграції. В оцінці наслідків трудової міграції для України найважливішим компонентом є настрої щодо повернення та їх реалізація. Якщо тимчасова відсутність має позитивні і негативні наслідки, то виїзд з України назавжди - майже виключно негативні. І в цьому контексті дуже оптимістичним видається бажання 65 \% потенційних трудових мігрантів повернутися до України навіть за наявності за кордоном постійної роботи. Безперечно, наміри можуть змінитися, але і настрої тих $23 \%$, хто волів би не повертатися, також не обов'язково реалізуються.

Враховуючи, що $41 \%$ українських трудових мігрантів у 2015-2017 рр. молодші за 35 років і тільки 20 \% старші за 50, неминучими наслідками масштабного відпливу економічно активного населення стануть:

1) брак робочої сили на місцевих ринках праці, спочатку за окремими професіями, а потім тотальний;

2) прискорення демографічного старіння, а отже, і збільшення навантаження на працююче населення;

3) посилення депопуляції, темпи якої вже впродовж 25 років є найвищими в Европі.

Навряд чи ринки праці східноєвропейських країн перестануть потребувати додаткову робочу силу в осяжній перспективі, тобто найбільш вірогідним видається збереження високого попиту на українських працівників. Та й не має вітчизняна влада жодних важелів впливу на ці процеси, на відміну від зменшення чисельності охочих працювати за кордоном. Отже, чи не єдиною можливістю скорочення масштабів трудової міграції з України є підвищення заробітної плати принаймні до 70-75 \% їхніх аналогів, зрозуміло, без втрати робочих місць. Але вже сьогодні інвестори (особливо закордонні) стикаються з проблемою найму на роботу місцевих працівників навіть за умови пропозиції зарплати на рівні 150-200 \% середньої по регіону. Безперечно, дається взнаки різна база орієнтації: інвестор порівнює свої пропозиції із офіційною заробітною платою, а населення - із своїми потенційними доходами від економічної діяльності, включно із тіньовими. Також демотивує офіційно ставати до роботи ризик втрати субсидії на оплату житлово-комунальних послуг. Тому держава має поступово зменшувати масштаби надання субсидій, принаймні працездатному населенню, звісно без зниження рівня життя.

Поки що певних труднощів зазнають ринки праці західних областей України та ті підприємства, які за характером своєї діяльності стикаються з робочою силою високої мобільності, зокрема будівельні. Більшість же роботодавців, які не мають потреби у масштабному наймі працівників, ще не відчувають гостроти проблеми. За результатами їх опитування, головними перешкодами розвитку бізнесу в Україні $є$ зависокі загальнодержавні податки (47,5 \% загальної чисельності опитаних), часта зміна правил і законів ведення бізнесу (30,3 \%), високі відсоткові ставки за банківськими кредитами $(25,1 \%)$, відсутність програм підтримки бізнесу на державному рівні $(22,1 \%)$ [7]. Але економічне зростання відбуватиметься не тільки за рахунок підвищення продуктивності праці на наявних підприємствах, потрібно буде розвивати нові види діяльності, що потребуватиме нових виробничих потужностей, а отже, i найму нових працівників. Тоді обмежена пропозиція робочої сили майже неминуче перетвориться на бар'єр розвитку і бізнесу, і економіки країни в цілому. 
Однак не тільки ринком праці обмежуються наслідки трудової міграції. Страждають сімейні стосунки - багато шлюбів руйнується через тривалу або систематичну відсутність одного з подружжя. Подеколи виїжджають обоє батьків або мати з неповної сім’ї, а діти взагалі залишаються на бабусю (дідуся, старшу сестру, старшого брата, іншого родича), тобто без батьківського піклування. Зрозуміло, що такі діти, не маючи взірців нормального родинного життя, майже неминуче матимуть проблеми і в своєму майбутньому шлюбі.

Поширюється внаслідок бездоглядності і ювенальна злочинність. Звикаючи до «легких грошей» і абсолютно не розуміючи, наскільки важкою є праця батьків за кордоном, підлітки радше вдаються до злочинів, але аж ніяк не орієнтуються на легальну трудову діяльність. Однак ця теоретична конструкція не підтверджується статистикою. Наразі важко відокремити імовірні похибки інформації від реальних тенденцій. Проте, зрозуміло, що відсутність принаймні одного з батьків не може не впливати на світогляд дитини.

Є також свідчення переважної налаштованості дітей трудових мігрантів на життя за кордоном.

Самі трудові мігранти після повернення на батьківщину мають проблеми із пенсійним забезпеченням, оскільки у більшості випадків не сплачують необхідних страхових внесків. Це не мало особливого значення за практичної відсутності зв'язку між розміром пенсії і сумою сплачених до Пенсійного фонду України внесків, але тепер, коли соціальна пенсія призначається у старшому віці і меншому розмірі, ніж трудова, може стати важливим.

До того ж більшість заробітчан не мають за кордоном повного соціального пакету - це є абсолютно неминучим за умови нелегальної зайнятості і поширеним за умови легальної. Своєю чергою такий недостатній соціальний захист часто спричиняє проблеми з відшкодуванням втрати доходів заробітчан через виробничу травму / інвалідність, з лікуванням та подальшою реабілітацією. Відповідно частина цих проблем переноситься на «територію витоку мігрантів».

Найгостріші для майбутнього країни загрози пов'язані із учбовою міграцією, оскільки наявність відповідного диплому значно спрощує працевлаштування в європейських країнах, при чому не тільки сусідніх. Це означає не просто втрату робочої сили, а скорочення демографічного потенціалу українського суспільства, прискорення процесу демографічного старіння тощо. Наразі навчальні заклади багатьох європейських країн охоче запрошують українців і досит часто надають певні пільги для вступу та оплати навчання, проживання, користування лабораторіями, бібліотеками, спортивними закладами. Відповідна реклама дуже активна, часто агенти працюють безпосередньо у школах. При цьому упереджене ставлення до робітничих професій, пов'язане, зокрема, із їхнім низьким соціальним статусом, не поширюється на інші країни - українці не вважають для себе і своїх дітей неприйнятною таку роботу за кордоном. Імовірно, дається взнаки і загалом шанобливе ставлення до будь-якої легальної зайнятості тамтешнього населення - з одного боку, і відсутність там сильних соціальних зв'язків українців - з другого.

Важливою складовою наслідків поширення трудової міграції є кошти, які надходять до України і допомагають виживати не тільки безпосереднім їх отримувачам, а й цілим поселенням. За оцінками Нацбанку України, в 2017 році приватні перекази становили 9,3 млрд дол. США, тобто 8,4 \% ВВП країни. Це учетверо перевищує чистий приплив прямих іноземних інвестицій, які становили 2,3 млрд [8]. Звісно, на відміну від ПІІ тільки невелика частина приватних грошових переказів спрямовується на відкриття бізнесу, але кожна гривня, витрачена в Україні, так або інакше 
працює на вітчизняну економіку. Навіть якщо гроші витрачаються на поточне споживання, вони збільшують сукупний платоспроможний попит, а отже, створюють передумови для заробітків (звісно, далеко не завжди легальних) доволі широкому загалу. Достатньо проаналізувати територіальну диференціацію новобудов у сільській місцевості, зокрема, звернути увагу на різницю між поселеннями, багато мешканців яких працюють за кордоном, і тими, де заробітчан практично нема. 3 огляду на нерівномірність територіального розподілу і приватних грошових переказів, і прямих іноземних інвестицій, слід зробити висновок, що принаймні ті територіальні громади, звідки виїжджає на заробітки багато людей, отримують безумовний зиск.

Треба також мати на увазі, що за кордон виїжджають ті, кого не влаштовують можливості українського ринку праці, хто радше волів би працювати нелегально, часто реєструючись у службі зайнятості і претендуючи на різні види соціальної допомоги. За умов еміграції саме цієї категорії зменшується загальний тиск на систему соціальної підтримки населення і знижується штучна конкуренція за робочі місця - наявність значної чисельності зареєстрованих безробітних, які насправді не хочуть працювати, тільки провокує консервацію низького рівня оплати праці.

Отже, наслідки масштабної трудової міграції є дуже різними. Оцінювати значення і наслідки кожного конкретного виду міграцій варто з урахуванням інтересів світового розвитку, країни витоку мігрантів та їхніх родин.Сучасна зовнішня міграція українців складається із шести компонентів (рис. 3).

Перша складова - виїзд на постійне місце проживання до іншої країни; такі прагнення, часто приховані, мають і ті, хто їде за кордон з декларованою метою роботи або навчання. Цей вид міграцій, очевидно, є безповоротним і означає прямі втрати України: скорочується загальна чисельність населення і сукупна пропозиція робочої сили, втрачаються ресурси, витрачені на професійно-освітню підготовку мігрантів. Перспективи пов'язані виключно із підтримкою контактів із емігрантами, із допомогою їм у збереженні зв’язків з Україною та сподіваннями на те, що вони або (бодай частково) повернуться, або формуватимуть позитивний імідж України за кордоном. Переважно мігранти, які виїжджають з такими намірами, або відразу прямують до нової країни цілими сім'ями, або забирають туди своїх близьких за програмою воз'єднання сімей. Отже, родинні стосунки від цього практично не страждають.

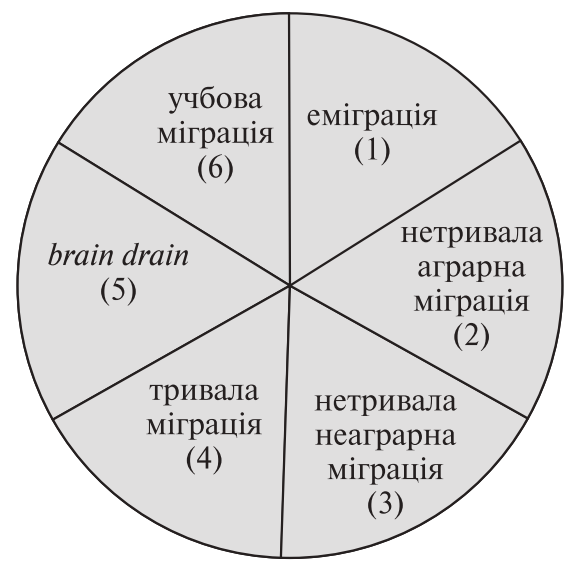

Рис. 3. Складові сучасної зовнішньої міграції українців

Джерело: складено автором. 
Друга складова - короткотермінова (найчастіше сезонна) трудова міграція, переважно пов'язана зі збиранням урожаю, яка охоплює, головним чином, робочу силу низької кваліфікації та студентів, - не справляє негативного впливу ані на ринок праці, ані на соціально-демографічну ситуацію в Україні. Через ії виражену сезонність особи низької та середньої кваліфікації, які не мали потреби (можливості) постійного / довготривалого працевлаштування в Україні, повертаються на батьківщину із заробленими грошима, новими контактами, соціальними зв'язками та навичками поведінки в демократичному суспільстві з ринковою економікою. Сезонна міграція, головним чином через свою нетривалість, не віддзеркалюється помітно на ситуації в родинах мігрантів. Тому цю складову варто оцінювати радше позитивно.

Короткотермінова трудова міграція працівників низької та середньої кваліфікації, орієнтованих на неаграрний сектор, переважно, не має вираженої сезонності (за винятком зайнятості в туристичному бізнесі). Відповідно існує висока імовірність переходу більш успішних заробітчан у категорію довготривалих мігрантів. А довготривала відсутність справляє негативний вплив на ситуацію і в родині, зокрема щодо догляду та виховання дітей, сталості шлюбу тощо, і на ринку праці. Позитивні наслідки пов’язані переважно із коштами, що їх надсилають мігранти з-за кордону, та сподіваннями на їхнє повернення з новими знаннями та навичками. Однак навіть ті, хто працює понад рік, зайняті, головним чином, тимчасовими (часто сезонними) роботами або такими, що не потребують високої кваліфікації: обов’язки 36 \% (56 \% в Італії, 46 \% в Польщі, 35 \% в Чехії) мігрантів, які повернулися до України, не потребували кваліфікації [5]. Це означає набуття українськими заробітчанами дуже важливого досвіду спілкування в ринковій економіці, але не сучасної кваліфікації.

Четверта складова - довготермінова трудова міграція доволі кваліфікованих працівників - охоплює передусім газо- та електрозварювальників, медиків, будівельників, водіїв-далекобійників, швачок; їхній від’їзд вочевидь негативно позначається на українському ринку праці. Знайти їм заміну дуже важко, отже підприємства вже зараз потерпають від браку фахівців відповідних професій. До цього додаються загальні соціально-демографічні проблеми, пов'язані із довготривалою відсутністю одного/обох батьків.

П'ята складова - це brain drain, тобто відплив висококваліфікованих науковців, освітян, медиків, акторів тощо. На жаль, здебільшого ця трудова міграція трансформується в еміграцію і спричиняє очевидні незворотні втрати української економіки (науки, освіти, медицини, промисловості тощо), проте сприяє піднесенню світового розвитку. Тому оцінка має бути негативною, виходячи з інтересів країни витоку, але позитивною з огляду на інтереси самих мігрантів та їхніх родин i, безумовно, з огляду на розширення можливостей прогресу.

Нарешті, учбова міграція до вищих і середніх професійних навчальних закладів, зазвичай, означає подальше працевлаштування молоді за кордоном з усіма негативними економічними і демографічними наслідками для України. При чому якщо привабливими середніми професійними навчальними закладами є виключно європейські, то серед привабливих вишів є і російські. Альтернатива пов'язана виключно 3 орієнтацією молоді на вітчизняні професійно-освітні заклади, з підвищенням їхнього престижу, ефективною роз'яснювальною роботою серед молоді тощо. Учбова міграція зросла з 2009 до 2016 рр. на 76 \% (за два останні роки - на 20), причому дві третини цього приросту обумовили польські університети [9]. Українці наразі становлять $57 \%$ іноземних студентів польських університетів, але обирають вони переважно приватні виші, що не обіймають високих позицій у рейтингах. Характерно, що най- 
більше зростає чисельність українських студентів саме в тих країнах, якіє головними центрами тяжіння українських мігрантів, і де існують потужні міграційні мережі. Опосередковано це свідчить про возз'єднання сімей трудових мігрантів у країнах їхнього перебування.

Переважна частина молоді, яка виїжджає на навчання за кордон, розглядає набуття освіти в європейському закладі і отримання відповідного диплому як можливість працевлаштування на ринку праці ЄС. Цьому сприяє і передбачений законодавством Євросоюзу дозвіл іноземцям на перебування в ЄС щонайменше упродовж 9 місяців після завершення навчання. Цей час може бути успішно використаний для пошуку робочого місця. В результаті повернення на Батьківщину планують не більше 13-16 \% українських студентів у Пшемишлі [10] і лише 2 \% - у варшавському регіоні [11].

Можливості впливу на міграційну поведінку. В контексті формування державної політики важливо сприйняти невідворотність масштабного зовнішнього обміну населенням. Допоки рівень життя в Україні залишатиметься низьким, сальдо міграцій буде негативним. Коли ж заробітки, система соціальної підтримки, соціо-політична стабільність стануть співставними принаймні з аналогами східно-європейських країн, необхідно буде вирішувати проблеми масштабної імміграції. Скоріше за все, роботодавці перестануть потерпати через брак робочої сили, але на порядку денному неминуче стануть завдання адаптації іммігрантів до української культури та способу життя українців за одночасного створення їм умов для власного культурного розвитку. Насправді це не менш складне завдання, особливо з огляду на те, що їдуть завжди люди з бідніших та нестабільніших країн до таких, де вища якість життя і потужніша соціальна підтримка. Розрахунки на те, що Україна зможе фільтрувати потік іммігрантів, радше не виправдаються, тому що досі цим не може похвалитися жодна держава навіть із потужним імміграційним контролем.

Безперечно, глобалізація створює передумови вільного переміщення робочої сили між країнами та континентами. Масштабний відплив економічно активного населення до країн із вищими зарплатами та кращими можливостями працевлаштування, кращою освітою тощо є практично неминучим. Як і т. зв. відтік мізків до країн із кращими можливостями проведення наукових досліджень - на відміну від пересічного емігранта мотивом виїзду науковця, хірурга, винахідника тощо є не тільки (і навіть не стільки) низька зарплата. I молодь, яка вбачає у дипломі західного навчального закладу свою «перепустку» на ринок праці розвиненої країни, буде прагнути вчитися за кордоном, хоча цілком імовірно, що рівень підготовки в українському навчальному закладі зовсім не поступається тому, що можна отримати за кордоном. І навіть за умови дуже швидкого соціально-економічного розвитку і досягнення рівня та якості життя, співставних зі стандартами розвинутих стабільних суспільств, зовнішній міграційний обмін населенням відбуватиметься. Більше того, скоріше за все, масштаби зовнішніх міграцій зростатимуть.

Але можна зменшити їх потенційний обсяг, зокрема шляхом переорієнтації частини потенційних мігрантів на розвинутіші ринки праці інших міст України, можна підвищити налаштованість мігрантів на повернення на Батьківщину. Для цього потрібні комплексні дії й усвідомлення того, що економічне зростання автоматично не спричинить зміну міграційних потоків.

У суспільстві необхідно формувати повагу до працюючої людини незалежно від іiі професії, посади та заробітків. Подолання утриманських настроїв, крім усього іншого, і означає домінування в суспільстві переконання в тому, що соромно жити на соціальні трансферти і не платити податки, а працювати на будь-якій посаді 
шановано і престижно. Вкрай потрібною є трансформація соціальної підтримки працездатного населення, зокрема, стимулювання активної поведінки на ринку праці (зайнятості, підприємництва, самозайнятості, сімейного бізнесу тощо), підвищення диференціації пенсій відповідно до тривалості страхового стажу, вибудова і дотримання співвідношень мінімальних державних гарантій (мінімальна заробітна плата має істотно перевищувати всі інші за винятком адресованих людям з особливими потребами).

Безперечно, необхідно домагатися підвищення рівня оплати праці. Звісно, в ринковій економіці держава має небагато важелів впливу в цій сфері. Один із таких важелів - дворазове підвищення мінімальної заробітної плати - нещодавно використано. Розраховувати на такий же ефект у найближчій перспективі не варто (власне, це довело і підвищення мінімальної зарплати на 16 \% з 01.01.2018). Тому залишається підвищення зарплат у бюджетній сфері. Йдеться головним чином про вчителів, медиків, науковців, соціальних працівників, працівників музеїв, бібліотек, театрів. За принципом «сполучених сосудів» 3 певним лагом (за оцінками, у 3-6 місяців) відреагує і приватний сектор. Але для прискорення цього реагування і набуття ним бажаних параметрів необхідне державне / місцеве заохочення достворення робочих місць із прийнятною оплатою праці шляхом зниження масштабів корупції та неофіційних платежів, співробітництва з організаціями роботодавців, активізації роботи за генеральною та галузевими тарифними угодами, співробітництва з територіальними громадами, зокрема зміною системи оподаткування.

Розраховувати на помітне зменшення масштабів відпливу населення можна тільки за умови підвищення середньої зарплати принаймні до 70-75 \% аналогів східноєвропейських країн. Але і тоді налаштованість на еміграцію через високий потенціал збережеться.

Важливою і перспективною є переорієнтація потенційних трудових мігрантів, особливо з сіл та невеликих міст, із зовнішнього на внутрішній ринок праці. Цьому сприятиме, по-перше, будівництво та ремонт дорог, відновлення транспортної мережі. Результатом стане інтеграція локальних ринків праці в єдиний національний чи у низку регіональних. Це дасть можливість мешканцям сіл та невеликих міст жити вдома, а працювати на умовах маятникової міграції у містах із більш розвинутим ринком праці. По-друге, нагальною необхідністю є формування ринку тимчасового і соціального житла. Це забезпечить доступність тимчасової роботи у віддалених поселеннях, передусім молодим людям, які шукають свою професію, свою долю. Нарешті, по-третє, державні інвестиції в будівельну галузь створять сучасні робочі місця і в будівництві, і в дотичних галузях, у випадку дорожнього будівництва також і в готельному, ресторанному бізнесі, обслуговуванні автотранспорту тощо.

Нагально необхідним є поєднання загальних напрямів та заходів, що матимуть на меті зменшення масштабів відпливу населення, із специфічними, орієнтованими на конкретні контингенти мігрантів. Скажімо, бажання від’їду науковців є наслідком не тільки низьких заробітків, а й неприйнятним ставленням з боку влади і суспільства до науки, відсутністю можливостей купувати необхідне обладнання, літературу, брати участь у різноманітних наукових форумах тощо. Для зниження масштабів учбової міграції українські навчальні заклади мають осучаснити навчальні програми, сприяти контактам студентів з потенційними роботодавцями, створити дійсно потужні науково-навчальні центри, забезпечити можливості індивідуальної підготовки та дозвілля, тобто стати реальною альтернативою закордонним інституціям. 3 огляду на поширення в сусідніх країнах практики безкоштовного навчання іноземців варто 
більш системно підійти й до самого існування та вартості контрактної форми навчання в Україні.

Дуже важливим є налагодження систематичної взаємодії з українськими заробітчанами, навіть із тими, хто працює за кордоном вже кілька років і вивезли туди всю свою родину, включно із дітьми та старими батьками. Ці люди переважно все ще відчувають себе українцями, зберігають українське громадянство і українську мову. Тому вкрай необхідно підтримувати ці їхні відчуття і допомагати в реалізації, зокрема, шляхом організації навчання дітей в українських школах за українськими підручниками і програмами. Можна сподіватися, що бодай невелика їх частина повернеться до України. Але навіть якщо цього не станеться, ці люди будуть репрезентувати позитивний імідж України за кордоном, що є винятково важливим.

Загалом же видається, що Україна, насамперед, завдяки своєму географічному розташуванню, клімату, природним ресурсам, доброзичливому населенню, достатньо розвиненій інфраструктурі тощо, має всі шанси повторити шлях середземноморських країн, передусім Італії, які упродовж тривалого часу були донорами робочої сили для більш розвинених країн, але потім перетворилися на реципієнтів, при чому стали приймати робочу силу не тільки з бідних країн Азії та Африки, а і з достатньо розвинених і навіть більш заможних країн Європи. Необхідними умовами для цього є наявність конкурентних робочих місць із прийнятними умовами та оплатою праці, політична стабільність в країні і позитивна динаміка рівня та якості життя.

Висновки. Міграційний обмін населенням є невід’ємною складовою процесу глобалізації, і що далі, то більше зростатимуть масштаби зовнішньої міграції, все більше людей житимуть за межами країни свого походження і впродовж життя неодноразово змінюватимуть країну проживання.

Зміна пріоритетів для потенційних мігрантів, зокрема переорієнтація значної їх частини з Росії на європейські країни, є невипадковою і матиме сталий характер. У перспективі і Польща імовірно втратить своє значення головного центру тяжіння українських мігрантів - складна ситуація на ринках праці практично всіх розвинутих країн неминуче спонукатиме їх спрощувати процедури працевлаштування іноземців.

Наразі міграція - і трудова, i, ще більшою мірою, освітня - для значної частини українців виконує функції соціального ліфта, забезпечуючи можливості швидкого підвищення рівня життя і надаючи «перепустку» до ринків праці розвинутих, переважно європейських, країн.

Головним мотивом виїзду більшості українців є, безперечно, надія отримувати значно більшу зарплату. Але економічні чинники завжди діють у певному ментальному середовищі, зокрема реалізованому в конкретному рівні міграційної мобільності. Міграційна мобільність українців (як і поляків, німців, естонців, литовців, ірландців, італійців) є доволі високою на відміну від, наприклад, французів, угорців, болгар. Тому підвищення зарплат до співставного з сусідніми країнами рівня, безперечно, зменшить масштаби поширення міграційних настроїв, але не скасує їх повністю.

\section{ЛІТЕРАТУРА}

1. Настрої серед українців-заробітчан. - 01.02.2017 / Соціологічна група «РЕЙТИНГ» [Електронний pecypc]. - Режим доступу : http://ratinggroup.ua/research/ukraine/nastroeniya_sredi_ukraincevzarobitchan.html (дата звернення: 05.07.2018). 
2. Кровотечение. Почему украинцы покидают свою страну / Дзеркало тижня; Київський міжнародний інститут соціології [Електронний ресурс]. - Режим доступу : https://zn.ua/project/ emigration (дата звернення: 05.07.2018).

3. Динаміка міграційних настроїв українців. - 03.10.2017 / Соціологічна група «РЕЙТИНГ» [Електронний ресурс]. - Режим доступу: http://ratinggroup.ua/research/ukraine/dinamika_migracionnyh_nastroeniy_ukraincev.html (дата звернення: 05.07.2018).

4. Міграційні настрої населення України у квітні 2018 року / Київський міжнародний інститут соціології [Електронний ресурс]. - Режим доступу: http://kiis.com.ua/?lang=ukr\&cat=reports$\& \mathrm{id}=765 \&$ page $=1$ (дата звернення: 05.07.2018).

5. Зовнішня трудова міграція населення України (за результатами модульного вибіркового обстеження) / Державна служба статистики України [Електронний ресурс]. - Режим доступу: http://www.ukrstat.gov.ua/druk/publicat/kat_u/2017/bl_ztmz-2017.zip

6. Перехід на ринок праці молоді України: результати міжнародного дослідження «School-to-work transition surveys» в Україні у 2013 та 2015 роках / Елла Лібанова, Олександр Цимбал, Олег Ярош та Лариса Лісогор; Міжнародне бюро праці. - Женева, МОП, 2016. -123 с. [Електронний ресурс]. Режим доступу: http://www.idss.org.ua/monografii/2016_Zvit_rynok_pratsi.pdf (дата звернення: 05.07.2018).

7. Сприятливе середовище для сталих підприємств в Україні. - Київ, 2017. - С. 58.

8. Профіцит платіжного балансу України істотно зріс у 2017 році : прес-реліз. - 31.01.2018 / Національний банк України [Електронний ресурс]. - Режим доступу: https://bank.gov.ua/control/ uk/publish/article?art_id=63075631\&cat_id=55838 (дата звернення: 05.07.2018).

9. Стадний $\Theta$. Українські студенти за кордоном: факти та стереотипи. - 19.12.2017 [Електронний pecypc]. - Режим доступу: https://cedos.org.ua/uk/jsvita/ukrainski-studenty-za-kordonom-faktyta-stereotypy (дата звернення: 05.07.2018).

10. Загайкало О. Освіта в Польщі як шлях в еміграцію? - 06.11.2015 // Дзеркало тижня [Електронний pecypc]. - Режим доступу: https://dt.ua/EDUCATION/osvita-v-polschi-yak-shlyah-v-emigraciyu_.html (дата звернення: 05.07.2018).

11. Chmielewska I., Dobroczek G., Puzynkiewicz J. A new wave of Ukrainian migration to Poland. - 19.01.2017 // Central European Financial Observer.eu [Електронний ресурс]. - Режим доступу: https://financialobserver.eu/poland/a-new-wave-of-ukrainian-migration-to-poland (дата звернення: 05.07.2018).

\section{REFERENCES}

1. Nastroi sered ukraintsiv-zarobitchan [The mood among the Ukrainian-workers]. (2017). Sociological group «RATING». ratinggroup.ua. Retrieved from http://ratinggroup.ua/research/ukraine/ nastroeniya_sredi_ukraincev-zarobitchan.html [in Ukrainian].

2. Krovotechenie. Pochemu ukraincy pokidajut svoju stranu [Bleeding. Why do Ukrainians leave their country?]. (n.d.). Dzerkalo tyzhnia - Mirror of the week. $z n . u a$. Retrieved from https://zn.ua/project/ emigration [in Russian].

3. Dynamika mihratsiinykh nastroiv ukraintsiv [Dynamics of migratory sentiment of Ukrainians]. (2017). Sociological group «RATING». ratinggroup.ua. Retrieved from http://ratinggroup.ua/research/ ukraine/dinamika_migracionnyh_nastroeniy_ukraincev.html [in Ukrainian].

4. Mihratsiini nastroi naselennia Ukrainy u kvitni 2018 roku [Migration attitudes of the population of Ukraine in April 2018]. (2018). Kyiv International Institute of Sociology. kiis.com.ua. Retrieved from http://kiis.com.ua/?lang $=$ ukr\&cat $=$ reports\&id $=765 \&$ page $=1$ [in Ukrainian].

5. Zovnishnya trudova mihratsiya naselennya Ukrayiny (za rezul'tatamy modul'noho vybirkovoho obstezhennya) [ External labor migration of the population of Ukraine (based on the results of a modular sample survey).] (2017). State Statistics Service of Ukraine. ukrstat.gov.ua. Retrieved from http://www.ukrstat.gov.ua/druk/publicat/kat_u/2017/bl_ztmz-2017.zip [in Ukrainian].

6. Libanova, E., Cymbal, O., Yarosh, O., \& Lisogor L. (2016). Perekhid na rynok pratsi molodi Ukrainy: rezultaty mizhnarodnoho doslidzhennia «School-to-work transition surveys» v Ukraini u 2013 ta 2015 rokakh [The transition to the labor market of Ukrainian youth: the results of the international study «School-to-work transition surveys» in Ukraine in 2013 and 2015]. International Labor Office. idss.org. ua. Retrieved from http://www.idss.org.ua/monografii/2016_Zvit_rynok_pratsi.pdf [in Ukrainian]. 
7. Spryiatlyve seredovyshche dlia stalykh pidpryiemstv v Ukraini [Favorable environment for sustainable enterprises in Ukraine]. (2017). Kyiv [in Ukrainian].

8. Profitsyt platizhnoho balansu Ukrainy istotno zris u 2017 rotsi : pres-reliz [The balance of payments of Ukraine increased significantly in 2017: a press release]. (2018). National Bank of Ukraine. bank.gov. ua. Retrieved from https://bank.gov.ua/control/uk/publish/article?art_id=63075631\&cat_id=55838 [in Ukrainian].

9. Stadnyi, E. (2017). Ukrainski studenty za kordonom: fakty ta stereotypy [Ukrainian Students Abroad: Facts and Stereotypes]. cedos.org.ua. Retrieved from https://cedos.org.ua/uk/jsvita/ukrainski-studentyza-kordonom-fakty-ta-stereotypy [in Ukrainian].

10. Zagaikalo, O. (2015). Osvita v Polshchi yak shliakh v emihratsiiu? [Education in Poland as a way to emigration?]. Dzerkalo tyzhnia - Mirror of the week. dt.ua. Retrieved from https://dt.ua/EDUCATION/ osvita-v-polschi-yak-shlyah-v-emigraciyu-_.html [in Ukrainian].

11. Chmielewska, I., Dobroczek, G., \& Puzynkiewicz, J. (2017). A new wave of Ukrainian migration to Poland. Central European Financial Observer.eu financialobserver.eu. Retrieved from https:// financialobserver.eu/poland/a-new-wave-of-ukrainian-migration-to-poland [in English].

Стаття надійшла до редакції журналу 05.07.2018. 